Gut, 1964, 5, 429

\title{
Spontaneous internal biliary fistulae
}

\author{
J. L. A. DOWSE \\ From Llandough Hospital, near Cardiff
}

EDITORIAL SYNOPSIS This paper provides a comprehensive account of the various types of spontaneous internal biliary fistulae and emphasizes the importance of chronic gall bladder disease in the aetiology. Air in the biliary tree is an important radiological sign. Early diagnosis and treatment of chronic cholelithiasis may prevent this complication.

The gall bladder lies on the under surface of the liver, and is held in position by areolar tissue and the peritoneum covering the under surface of the liver. It lies obliquely, its long axis being directed backwards and upwards and slightly medially from the lower anterior edge of the liver, to the right end of the porta hepatis. The fundus of the gall bladder is in close relation to the anterior abdominal wall. The transverse colon is closely related to the inferior surface of the fundus and body of the gall bladder, and the pylorus and first part of the duodenum lie below the neck of the gall bladder and cystic duct. The common bile duct descends in the free margin of the lesser omentum, passing behind the first part of the duodenum, to enter a groove in the head of the pancreas and open into the second part of the duodenum (Fig. 1). It is not surprising, therefore, that spontaneous internal biliary fistulae are most likely to form between the gall bladder and the first part of the duodenum (or pylorus) and the colon, and also between the common bile duct and the first part of the duodenum (or pylorus). Occasionally adjacent viscera are connected by multiple fistulae

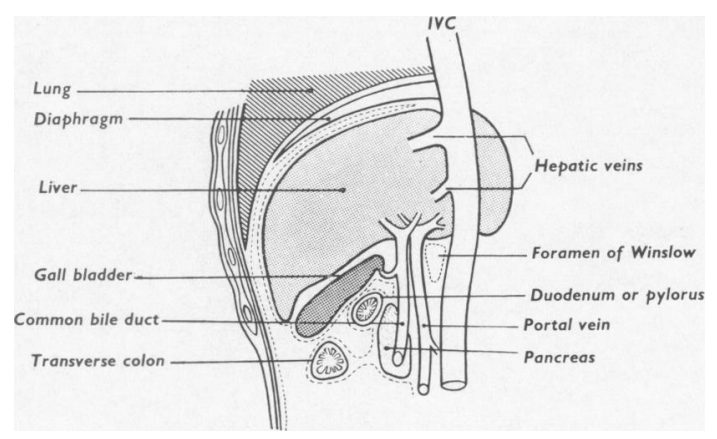

FIG. 1. Diagram of sagittal section through the ninth costal cartilage, indicating relations of the gall bladder. through the cavity of the gall bladder. The cases recorded by Faber are extremely unusual; of 13 gall stones, 'nine small and four large' voided in the urine 'without any symptoms of a remarkable nature except pains in the bladder'; of a fistula between the gall bladder and pregnant uterus, with the passage of gall stones during labour; of fistulous connexions between the gall bladder and portal vein, 'so that the vein has been filled entirely with stones' (Frerichs, 1861). Infections and injury of the biliary tract have caused extravasation of bile into the pleural cavity, 'bilithorax', and the expectoration of bile, 'biliptysis', due to the formation of a bronchopleural fistula (Adams, 1958). Even the pericardial sac has been found to contain gall stones.

There are two important causes of spontaneously forming internal biliary fistula: (1) chronic cholecystitis and (2) penetration of a peptic ulcer. Aird (1950) writes: 'Internal fistula of the gall bladder or cystic duct with duodenum, small intestine, or some other hollow viscus is usually due to the erosion of a stone during an attack of acute cholecystitis'. This view is upheld by the observations of Marshall and Polk (1958), who found that 28 of 30 cases of cholecystoduodenal fistula could be attributed directly to chronic gall bladder disease, whereas only two were the results of penetrating peptic ulcers. In two cases of choledochal fistula, however, one to the first part of the duodenum and the other to the pylorus, penetrating peptic ulcer was the cause in each case. Ulcerative colitis has produced fistulae between the colon and the gall bladder (Ormandy and Bargen, 1939), and malignant disease of the biliary tract, stomach, colon, and duodenum (Bisgard, 1942) has also produced internal biliary fistulae.

Two mechanisms are thought to be involved in the formation of spontaneous internal biliary fistulae. 1 Adhesions form between the gall bladder and adjacent viscera and necrosis of the wall of the 
gall bladder at the sites of adhesion leads to a fistula being formed by a direct tract or (2) an abscess may form around the gall bladder, bursting into contiguous hollow viscera, which then communicate indirectly through the abscess cavity (Robson, 1909).

As chronic cholecystitis occurs about twice as commonly in females as in males, it is not surprising that the occurrence of spontaneous internal biliary fistulae should follow this pattern. Judd and Burden (1925), reporting 153 cases from the Mayo Clinic, found 111 were in females and only 42 in males (2.64 to 1). Marshall and Polk (1958) at the Lahey Clinic reviewed 41 cases, 26 of which were in females and 15 in males (1.74 to 1). Most cases from both reports occurred in the sixth and seventh decades, the age at which gall bladder disease presents most commonly. Hutchings, Wheeler, and Puestow (1956), reviewing a series of 28 patients with choledochoduodenal fistula complicating duodenal ulcer, found the average age to be 45 years, rather younger than the age of patients with fistulae due to gall bladder disease, and all were male.

Borman and Rigler (1937) found 60 internal biliary fistulae in 30,000 necropsies $(0.2 \%)$, and in a series of 10,866 consecutive necropsies, Roth, Schroeder, and Schloth (reported by Robson, 1909) found 43 fistulae $(0.4 \%)$ Internal biliary fistulae have been found to be present in $1.2 \%$ of all cases of cholecystitis operated upon at the University of Iowa (Puestow, 1942), and Dean (1939) also records an incidence of $1.2 \%$ following 1,263 operations upon the biliary tract. Kehr (reported by Puestow,
1942), and Hutchings et al. (1956) found 100 internal biliary fistulae in 2,000 cholecystectomies, an incidence of $5 \%$. Hutchings et al. (1956) reported that between 10 and $20 \%$ of all spontaneous internal biliary fistulae were choledochoduodenal fistulae, $80 \%$ of which were due to penetration of a duodenal ulcer. However, all authors agree that cholecystoduodenal fistulae are the ones most commonly found. Table I indicates the site of fistula as reported by a number of writers and confirms the overwhelming predominance of the cholecystoduodenal type.

This series is small, yet reflects the findings of other investigators. Of the 13 cases, nine fistulae were due to erosion of gall stones, two to peptic ulceration, one to carcinoma of the stomach, and one to perforation of a duodenal diverticulum, possibly by a foreign body. A cholecystoduodenal fistula was present in seven cases, a cholecystocolic fistula in one, a cholecystogastric in one other, and a choledochoduodenal fistula in two cases. Two cases of multiple fistulae were found: one was a cholecysto-gastrocolic fistula and the other a cholecystoduodenocolic fistula (Fig. 2). Nine of the 13 cases were in females and four were in males (2.25 to 1$)$.

\section{SYMPTOMS AND SIGNS}

Marshall and Polk (1958) write: 'There are no specific symptoms which are diagnostic of internal biliary fistulae'. As most cases arise as a result of gall bladder disease, these will have a history of

TABLE I

SITE OF FISTULA AS REPORTED BY NINE AUTHORS

\begin{tabular}{|c|c|c|c|c|c|c|c|c|c|c|}
\hline \multirow[b]{2}{*}{ Type of Fistula } & \multicolumn{10}{|l|}{ Series } \\
\hline & $\begin{array}{l}\text { Courvoisier } \\
\text { and Naunyn } \\
\text { quoted by } \\
\text { Robson } \\
(1909)\end{array}$ & $\begin{array}{l}\text { Judd and } \\
\text { Burden } \\
\text { (1925) }\end{array}$ & $\begin{array}{l}\text { Dean } \\
(1939)\end{array}$ & $\begin{array}{l}\text { Wakefield, } \\
\text { Vickers, } \\
\text { and } \\
\text { Walters } \\
(1939 b)\end{array}$ & $\begin{array}{l}\text { Puestow } \\
\text { (1942) }\end{array}$ & $\begin{array}{l}\text { Carlson } \\
\text { and } \\
\text { Novacovich } \\
(1955)\end{array}$ & $\begin{array}{l}\text { Colcock } \\
\text { and } \\
\text { McManus } \\
(1955)\end{array}$ & $\begin{array}{l}\text { Marshall } \\
\text { and } \\
\text { Polk } \\
(1958)\end{array}$ & Personal & Total \\
\hline $\begin{array}{l}\text { Cholecystoduodenal } \\
\text { Cholecystocolic } \\
\text { Cholecystogastric } \\
\text { Choledochoduodena } \\
\text { Choledochocolic } \\
\text { Choledochogastric } \\
\text { Multiple } \\
\text { Others }\end{array}$ & $\begin{array}{l}93 \\
49 \\
8 \\
15 \\
1 \\
\\
\text { Gall bladder } \\
\text { to jejunum 1 } \\
\text { To ileum } 1 \\
\text { To urinary } \\
\text { tract } 6 \\
\text { To thorax } 10 \\
\text { Biliary tract } \\
\text { to itself } 8 \\
\text { Liver to } \\
\text { stomach } 4\end{array}$ & $\begin{array}{l}\frac{148}{-} \\
\overline{1} \\
\overline{-} \\
\text { Cystic duct } \\
\text { to } \\
\text { duodenum } 4\end{array}$ & 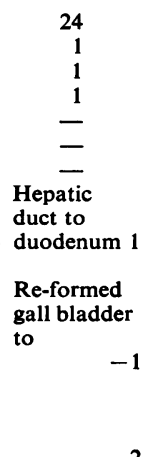 & $\begin{array}{r}101 \\
33 \\
7 \\
- \\
- \\
11 \\
-\end{array}$ & \begin{tabular}{l}
\multicolumn{1}{c}{9} \\
2 \\
1 \\
- \\
1 \\
$\begin{array}{l}\text { Gall bladder } \\
\text { to common } \\
\text { bile duct } 1\end{array}$ \\
$\begin{array}{l}\text { Hepatic } \\
\text { duct to } \\
\text { duodenum }\end{array}$ \\
$\begin{array}{l}\text { Hepatic } \\
\text { duct to } \\
\text { bronchus } 1\end{array}$
\end{tabular} & $\begin{array}{l}10 \\
1 \\
2 \\
- \\
- \\
- \\
-\end{array}$ & 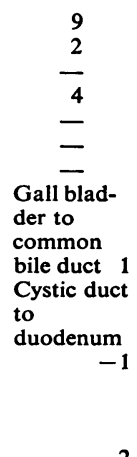 & $\begin{array}{l}30 \\
3 \\
2 \\
1 \\
-1 \\
1 \\
\text { Gall blad- } \\
\text { der to } \\
\text { common } \\
\text { bile duct } \\
\end{array}$ & $\begin{array}{l}7 \\
1 \\
1 \\
2 \\
\\
2\end{array}$ & $\begin{array}{r}431 \\
92 \\
22 \\
24 \\
-\quad \\
1 \\
15\end{array}$ \\
\hline & $196^{30}$ & 153 & 29 & 152 & 3 & 13 & 17 & 41 & 13 & $\begin{array}{r}44 \\
630\end{array}$ \\
\hline
\end{tabular}




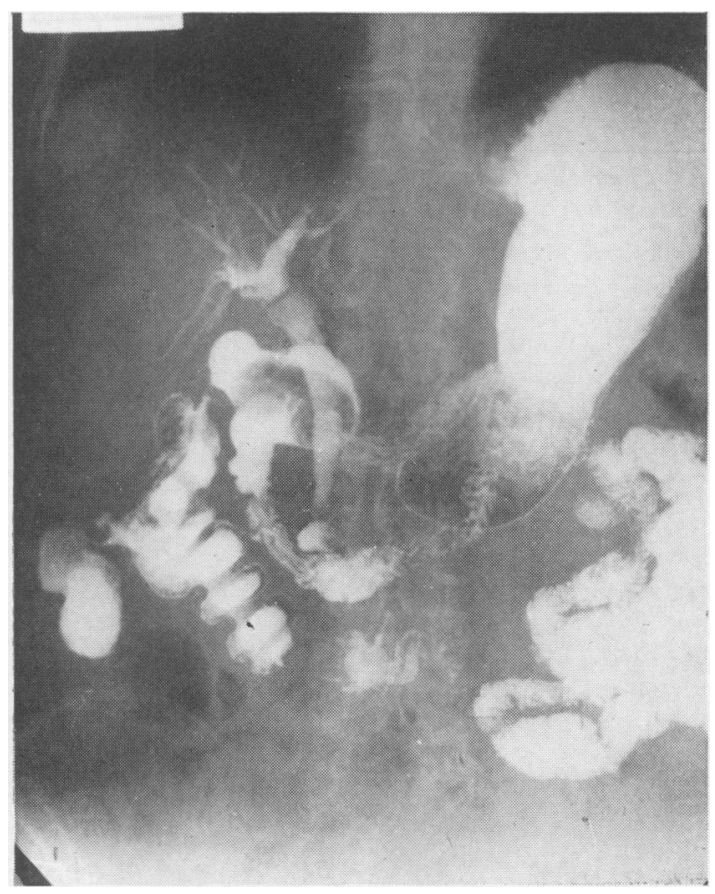

FIG. 2. Barium showing a radiotranslucent filling defect in the first part of the duodenum and fistulous communications between the gall bladder, duodenum, and colon.

cholecystitis, frequently of many years' duration. In this series, the duration of symptoms varied between five months and 30 years. Though Dean (1939) was of the opinion that the longer the history, the more likely a fistula to be present, I consider the duration of symptoms to be no guide in the diagnosis of spontaneous internal biliary fistulae, as in four cases in this series symptoms of gall bladder disease had been present for less than nine months. Pain is commonly a presenting symptom. This is usually in the epigastrium, often radiating to the right upper quadrant and to the back, simulating biliary colic in severity. There is no correlation between the severity of pain or its duration and the formation of the fistula. 'It is logical that the pain should decrease at the time of perforation and fistula formation in cases due to basic disease of the biliary tract' write Marshall and Polk (1958). This view is upheld by the observations of Judd and Burden (1925), whereas the contrary view is put forward by Puestow (1942), 'as the natural cure is worse than the disease'. The pain due to penetration of a peptic ulcer may show little change at the time of fistula formation, though with erosion of a peptic ulcer on to the posterior ab- dominal wall, pain assumes a boring quality and is felt in the back as well as in the epigastrium.

As nausea, vomiting, and flatulent dyspepsia are commonly presenting symptoms of chronic duodenal ulceration and cholecystitis, patients with internal biliary fistulae will often complain of these symptoms.

Weight loss was not a prominent feature in this series, being present in only four cases, and in fact three patients described an increase in weight. In Marshall and Polk's series, weight was lost in $58.5 \%$. Despite weight loss, however, nearly all the patients in this series remained overweight, a common finding in patients with chronic cholecystitis (Colcock and McManus, 1955).

Tenderness and rigidity in the right upper quadrant was present in five cases of this series, at the umbilicus in two, and in the epigastrium in one. The liver is occasionally palpable but is not usually of great size and is masked by the rigidity in the right upper quadrant. Chills, rigors, sweats, and high fevers, all symptoms of cholangitis, have been recorded in cases of cholecystenteric fistula by many authors (Judd and Burden 1925; Puestow, 1942; Carlson and Novacovich, 1955). Evidence of cholangitis, however, is rare in choledochal fistulae complicating peptic ulcer (Hutchings et al., 1956; Jordan and Stirrett, 1956).

Jaundice was present in three patients during the acute illness which brought them into hospital, and in all patients, this was obstructive in type. Other authors refer to the presence of jaundice in some of their cases, though it is not a prominent symptom. The liver function tests were carried out in eight of the cases in this series, and in five the values were within normal limits. In three, however, the results indicated obstructive jaundice, the serum bilirubin levels being $1.9 \mathrm{mg} . \%, 5 \mathrm{mg} . \%$, and $18 \mathrm{mg} . \%$; in no case were there changes in thymol turbidity or flocculation. It is probable, however, that with the development of hepato-cellular damage produced by a chronic fistula (Beaver, 1929), changes would be reflected in the liver function tests, plasma proteins, and prothrombin time. Anaemia is not a common finding and occurred in one patient only, following gastro-intestinal bleeding. A leucocytosis is common during the acute inflammatory episode.

Table II summarizes the clinical features in the series.

\section{DIAGNOSIS}

There is no characteristic story of internal biliary fistula and the diagnosis will rarely be made preoperatively. In only two of 16 cases reported by Puestow was this done, and in only two of the 53 
TABLE II

CLINICAL FINDINGS IN THE PRESENT SERIES

\begin{tabular}{|c|c|c|c|c|c|}
\hline Case & $\begin{array}{l}\text { Age } \\
\text { (yr.) }\end{array}$ & Sex & Symptoms & Signs & Radiographs \\
\hline 1 M.P. & 77 & $\mathbf{F}$ & $\begin{array}{l}\text { Twelve days intermittent intestinal colic; } \\
\text { absolute constipation; faecal vomiting; } \\
\text { similar attack } 5 \text { months earlier }\end{array}$ & $\begin{array}{l}\text { Obese; abdomen distended, } \\
\text { tender in L.U.Q., no guarding or } \\
\text { rigidity; not jaundiced; bowel } \\
\text { sounds suggested distended loops }\end{array}$ & $\begin{array}{l}\text { Dilated loops of small intestine } \\
\text { with multiple fluid levels; no gall } \\
\text { stones visualized }\end{array}$ \\
\hline 2 A.C. & 60 & $\mathbf{M}$ & $\begin{array}{l}\text { Six months earlier attack of biliary colic } \\
\text { and cholecystitis; } 10 \text { days similar attack } \\
\text { with onset of obstructive jaundice; loss of } \\
\text { weight over } 6 \text { months }\end{array}$ & $\begin{array}{l}\text { Slight epigastric tenderness, no } \\
\text { guarding or rigidity; not jaundiced }\end{array}$ & $\begin{array}{l}\text { Cholecystogram showed lack of } \\
\text { function }\end{array}$ \\
\hline 3 H.J. & 74 & $\mathbf{M}$ & $\begin{array}{l}\text { Cholecystitis } 5 \text { years ago; generally } \\
\text { unwell for a year with loss of weight and } \\
\text { energy and jaundice; } 2 \text { weeks febrile } \\
\text { illness with vomiting and severe diarrhoea }\end{array}$ & $\begin{array}{l}\text { Thin, wasted, not jaundiced now; } \\
\text { no abnormal physical signs in } \\
\text { abdomen, though evidence of weight } \\
\text { loss }\end{array}$ & $\begin{array}{l}\text { Cholecystogram showed lack of } \\
\text { function }\end{array}$ \\
\hline 4 M.N. & 53 & $\mathbf{M}$ & $\begin{array}{l}\text { Three-week history of pain half an hour } \\
\text { after meals with vomiting; severe } \\
\text { exacerbation on admission, radiation to } \\
\text { right hypochondrium and the back, } \\
\text { obstructive jaundice for three weeks }\end{array}$ & $\begin{array}{l}\text { Thin, in pain, jaundiced; guarding } \\
\text { R.U.Q., with tenderness; diffuse } \\
\text { mass }\end{array}$ & \\
\hline 5 M.B. & 65 & $\mathbf{F}$ & $\begin{array}{l}\text { Many years history of peptic ulceration; } \\
9 \text { months ago an attack of biliary colic, } \\
\text { since then fat intolerance, general ill } \\
\text { health; weight increased }\end{array}$ & $\begin{array}{l}\text { Pale, fat, lax abdominal wall; not } \\
\text { jaundiced, liver slightly enlarged }\end{array}$ & $\begin{array}{l}\text { Cholecystogram showed lack of } \\
\text { function and a barium meal hour- } \\
\text { glass constriction }\end{array}$ \\
\hline 6 G.D. & 66 & $\mathbf{F}$ & $\begin{array}{l}\text { Fat intolerance } 12 \text { months; biliary colic } \\
\text { with cholecystitis and recurrent attacks of } \\
\text { cholangitis }\end{array}$ & $\begin{array}{l}\text { Fat, slightly jaundiced, tender } \\
\text { R.U.Q. }\end{array}$ & $\begin{array}{l}\text { Barium meal showed duodenal } \\
\text { diverticulum with reflux of barium } \\
\text { into common bile duct and gall } \\
\text { bladder }\end{array}$ \\
\hline 7 W.C. & 67 & $\mathbf{F}$ & $\begin{array}{l}\text { Twelve years' history of gastric ulcer } \\
\text { plus haematemesis; } 6 \text { months fat intoler- } \\
\text { ance, biliary colic }\end{array}$ & $\begin{array}{l}\text { Thin, epigastric tenderness and } \\
\text { guarding in right hypochondrium; } \\
\text { positive Murphy's sign }\end{array}$ & $\begin{array}{l}\text { Barium meal revealed pyloric stenosis } \\
\text { with chronic duodenal ulcer }\end{array}$ \\
\hline 8 M.D. & 69 & $\mathrm{~F}$ & $\begin{array}{l}\text { Emergency admission with acute } \\
\text { cholecystitis. Had had recurrent attacks } \\
\text { of biliary colic and cholecystitis over } \\
\text { several months }\end{array}$ & $\begin{array}{l}\text { Obese, generalized abdominal } \\
\text { tenderness, most marked in right } \\
\text { hypochondrium }\end{array}$ & $\begin{array}{l}\text { Straight radiograph several months } \\
\text { earlier showed two gall stones. On } \\
\text { this admission only one stone seen, } \\
\text { and later none seen }\end{array}$ \\
\hline 9 E.S. & 76 & $\mathbf{F}$ & $\begin{array}{l}\text { Thirty years' fat intolerance, } 4 \text { days' } \\
\text { biliary colic; } 24 \text { hours' faecal vomiting, } \\
\text { watery diarrhoea with earlier melaena }\end{array}$ & $\begin{array}{l}\text { Obese, lax skin; jaundice develop- } \\
\text { ing over a few days, positive } \\
\text { Murphy's sign }\end{array}$ & $\begin{array}{l}\text { Straight radiograph showed air in } \\
\text { the biliary passages; cholecysto- } \\
\text { gram revealed non-function. } \\
\text { Barium meal showed a filling defect } \\
\text { due to stone and a cholecysto- } \\
\text { duodenocolic fistula }\end{array}$ \\
\hline 10 F.N. & 63 & $\mathbf{M}$ & $\begin{array}{l}\text { Chronic duodenal ulcer history for } 22 \\
\text { years; emergency admission with haemate- } \\
\text { mesis and melaena }\end{array}$ & $\begin{array}{l}\text { Pale, melaena stool, slight } \\
\text { umbilical tenderness }\end{array}$ & $\begin{array}{l}\text { Barium meal revealed a choledocho- } \\
\text { duodenal fistula due to ulcer }\end{array}$ \\
\hline 11 A.P. & 47 & $\mathbf{F}$ & $\begin{array}{l}\text { Loss of appetite for } 3 \text { months, with } \\
\text { weight loss; epigastric pain, and a } \\
\text { feeling of distension relieved by nausea } \\
\text { and vomiting, past history of obstructive } \\
\text { jaundice and biliary colic a few years } \\
\text { earlier }\end{array}$ & $\begin{array}{l}\text { Pale, thin, with evidence of weight } \\
\text { loss; abdominal mass to right of } \\
\text { epigastrium; not jaundiced }\end{array}$ & $\begin{array}{l}\text { Barium meal showed carcinoma of } \\
\text { pars media with fistula to gall } \\
\text { bladder }\end{array}$ \\
\hline 12 H.B.J. & 69 & $\mathbf{F}$ & $\begin{array}{l}\text { Known case of ulcerative colitis for } 15 \\
\text { years and } 2 \text { years earlier had had a total } \\
\text { colectomy and ileostomy for this. Gall } \\
\text { stones recognized at operation then. } \\
\text { Now admitted with } 2 \text { days' history of } \\
\text { intestinal colic and vomiting, ileostomy } \\
\text { not functioning; no history suggestive of } \\
\text { gall bladder disease }\end{array}$ & $\begin{array}{l}\text { Dehydrated, abdomen distended, } \\
\text { visible peristalsis, not jaundiced, } \\
\text { not tender }\end{array}$ & $\begin{array}{l}\text { Straight radiograph of abdomen } \\
\text { revealed dilated loops of small bowel }\end{array}$ \\
\hline 13 E.B. & 81 & $\mathbf{F}$ & $\begin{array}{l}\text { Many years' history of ulcer type pain } \\
\text { with vomiting and a sliding hiatus hernia } \\
\text { had been recognized on barium studies. } \\
\text { Four days' spasmodic pain like intestinal } \\
\text { colic with a lot of vomiting }\end{array}$ & $\begin{array}{l}\text { Not jaundiced, 'looked well for } 81 \\
\text { year old', minimal congestive heart } \\
\text { failure, distended abdomen; bowel } \\
\text { sounds high pitched with distended } \\
\text { loops, slight tenderness in right } \\
\text { hypochondrium }\end{array}$ & $\begin{array}{l}\text { Straight radiograph of abdomen } \\
\text { revealed distended small bowel with } \\
\text { fluid levels and an opacity in the } \\
\text { R.L.Q. }\end{array}$ \\
\hline
\end{tabular}


TABLE II-continued

CLINICAL FINDINGS IN THE PRESENT SERIES

Gall stone ileus (stone $5.2 \times 2.8 \mathrm{~cm}$.) Gall bladder contained multiple stones; dense adhesions around cholecystoduodenal fistula

Acute inflamed gall bladder, stone, $1 \frac{1}{2} \mathrm{~cm}$. diameter, eroding through Hartman's pouch into duodenum; common bile duct dilated but exploration revealed no stones. Cholecystectomy

Normal values

Serum bilirubin $18 \mathrm{mg} . \%$; and alkaline phosphatase 43 K.-A. units

Normal values

Serum bilirubin $5 \mathrm{mg}$. \% alkaline phosphatase 27 K.-A. units

Normal values

Serum bilirubin $1.9 \mathrm{mg}$. $\%$ and alkaline phosphatase 20 K.-A. units

Normal values

No operation

Normal values

Laparotomy only

Gall stone ileus, stone impacted 6 in. from ileostomy stoma. Stone crushed within the bowel, and 'milked through' ileostomy. No other stones found in bowel or in region of

Gall stone ileus, stone impacted in jejunum $3 \mathrm{ft}$. from duodeno-jejunal flexure; dense adhesions around gall bladder; no other stones felt.

At necropsy cholecystoduodenal fistula. Two other stones remained in gall bladder. Common bile duct free from residual stones verse colon, stomach, and shrunken gall tion revealed multiple small stones, debris,

Chronic cholecystitis with fistula into duobiliary debris cholecystectomy followed by

Chronic cholecystitis and stones with evidence Crion; small fistula in size; cholecystectomy

No operation. This patient had a laparotomy and it was recognized then that apart from a well-formed Meckel's diverticulum there whole of the small and large bowel impacted in common bile duct; cholecystec choledochostomy, and removal of stone hyperaemia and thickening in the ileum been impacted. Radiograph on the table showed no stones. Nothing done gall bladder

Cholecystoduodenal fistula due to stone

Died 4th day of electrolyte imbalance

Cholecystoduodenal fistula due to

Survival stone

Cholecystogastrocolic fistula due to stone

Survival

Cholecystoduodenal fistula due possibly to ulceration

Survival

Cholecystocolic fistula due to stone Survival

Choledochoduodenal fistula through a diverticulum possibly as a result of a foreign body

Cholecystoduodenal fistula due probably to gall stone

Cholecystoduodenal fistula due to stone

Survival

Cholecystoduodenocolic fistula

Died

due to stone

Choledochoduodenal fistula due to duodenal ulcer

Cholecystogastric fistula due to carcinoma of stomach

Cholecystoduodenal fistula due to stone

Cholecystoduodenal fistula due to stone
Died due to enterocolitis and electrolyte imbalance 
cases reported by Judd and Burden was the preoperative diagnosis known. However, certain radiological features are diagnostic of internal biliary fistula. The presence of air (Fig. 3) or barium (Fig. 4) outlining the biliary passages is indicative of an internal biliary fistula, with the exception of the rare case of reflux of air or barium into the common bile duct, through a patulous sphincter of Oddi. Barium from an enema examination may run into the gall bladder and biliary tree through a cholecystocolic fistula; this occurred in the two cases recognized before operation in Judd and Burden's series. Cholecystography is of no value in revealing the presence of a fistula, as it only demonstrates that the gall bladder is not functioning. Barium meal studies showed a fistula between the upper gastrointestinal tract and some part of the biliary tract in $17 \%$ of the series of Marshall and Polk and a cholecystocolic fistula was found in one of their cases by barium enema examination. In this series,

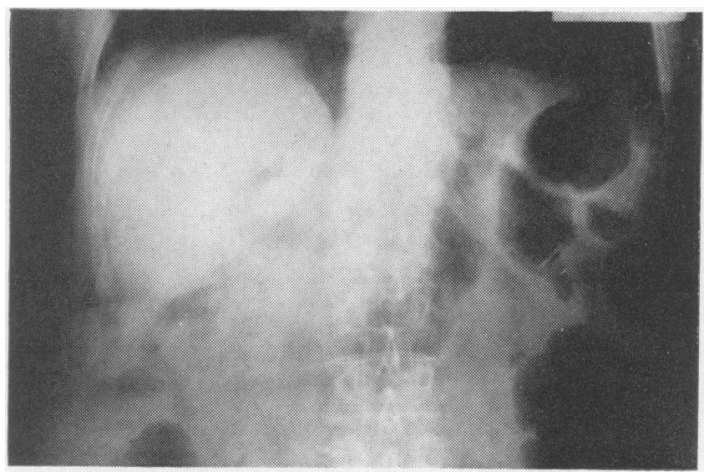

FIG. 3. Gas in the biliary tree in a case of cholecystoduodenal fistula.

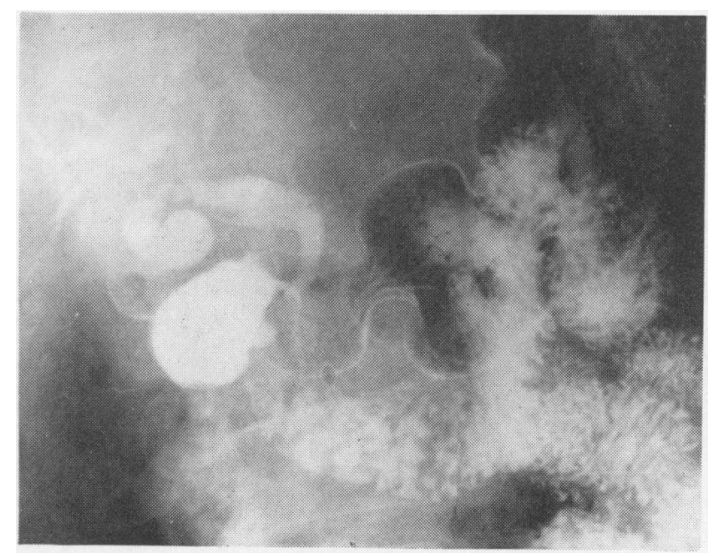

FIG. 4. Barium outlining the biliary tree in a case of choledocho-duodenal fistula due to duodenal ulcer. cholecystography was of value in one case, of cholecystoduodenocolic fistula. The oral dye was retained in the stomach and acted as a radioopaque meal outlining a smooth defect in the first part of the duodenum which was thought to be a gall stone. A barium meal confirmed that this was so, revealing the fistula between gall bladder, duodenum, and colon. This is a rare fistula, only five cases having been reported. However, a history of chronic cholecystitis and biliary colic, together with faecal vomiting and watery diarrhoea, is strongly suggestive of the presence of a cholecystoduodenocolic fistula (Dowse, 1963).

In a small number of cases, the gall stones, extruded through an internal biliary fistula, will obstruct the small bowel producing gall stone ileus. This occurred in three of the cases in this series. Characteristically, these patients have a long history of chronic cholecystitis over many years with more recent intermittent attacks of small bowel obstruction often, however, of many days' duration, so much so that on admission to hospital many patients are extremely ill as a result of dehydration and electrolyte imbalance. A straight radiograph of the abdomen in the erect position may reveal an opaque gall stone, the cause of the small bowel distension, and residual stones may be seen in the right upper quadrant of the abdomen. A gall stone large enough to cause intestinal obstruction usually reaches the bowel through a cholecystenteric fistula (Wakefield, Vickers, and Walters, 1939a).

\section{PROGNOSIS}

Because the gall bladder is always diseased, is usually small and contracted, containing foul, purulent bile and stones and retained duodenal content, 'the prognosis of cholecystoduodenal fistula secondary to gall stone ulceration is potentially poor' (Jordan and Stirrett, 1956). Rarely does the fistula provide adequate drainage within the surrounding dense scar tissue and stones are commonly retained within the gall bladder $(56 \%)$ and in the common bile duct $(29.3 \%)$ (Marshall and Polk, 1958). Judd and Burden found stones remaining in the gall bladder in $76(50 \%)$, in the cystic duct in $13(8.5 \%)$, and in the hepatic and common bile ducts in $66(43 \%)$ of their series of 153 cases of internal biliary fistulae upon which they operated. It is because of the retained stones and debris that recurrent attacks of cholangitis are likely. It has been suggested that there is a tendency for spontaneous fistulae to close unless there is permanent occlusion of the common bile duct, either from stone or retained food, and that minimal evidence may remain should the fistula close. 'On the other 
hand, the prognosis of choledochoduodenal fistula which is almost always secondary to duodenal ulceration is substantially better' (Jordan and Stirrett, 1956). In fact these are the most silent of internal biliary fistulae (Hutchings et al., 1956). Ascending cholangitis, so commonly a complication of fistulae as a result of chronic gall bladder disease, occurs less commonly in choledochoduodenal fistulae, and therefore progressive hepatocellular damage is avoided.

\section{TREATMENT}

In view of the poor prognosis of spontaneous internal biliary fistulae due to chronic gall bladder disease, the early prophylactic removal of the diseased gall bladder is advocated before fistulae can form; it is not considered safe merely to observe such cases (Wakefield et al., 1939b). The surgical management of internal biliary fistulae is tedious and hazardous. Dissection of the cystic duct and its junction with the common hepatic and common bile ducts is essential, and because these structures will be surrounded with dense fibrous tissues, their identification is difficult. Needle aspiration may be necessary in order to recognize these structures. If the cystic duct is wide and the common bile duct dilated, exploration of the common bile duct is indicated so as to recognize retained stones or foreign material. In $29.3 \%$ of Marshall and Polk's (1958) series and in $43 \%$ of Judd and Burden's (1925) series stones were found in the common bile duct. In the event of multiple small stones and debris being present, a choledochoduodenostomy may be indicated following the removal of stones. Cholecystectomy should always be carried out. The closure of the fistulous openings in the colon or duodenum presents little difficulty and the lumen of the bowel is rarely narrowed.

In the case of fistulae due to penetration of a peptic ulcer, the prognosis is considerably improved and therefore indications for surgery are limited to the complications of peptic ulceration, such as bleeding, obstruction, perforation, intractable pain, and cholangitis (Jordan and Stirrett, 1956; Marshall and Polk, 1958). However, Hutchings et al. (1956) believe that medical treatment produces equivocal results, and consider that such a fistula is unlikely to heal, due to inflammatory obstruction of the common bile duct. In their view, there are three objectives in the treatment of choledochoduodenal fistulae: 1 , healing of the duodenal ulcer; 2 , preventtion of regurgitation of duodenal content into the biliary tract; and 3, re-establishment of normal biliary continuity. In their series of five cases, one refused operation, one 58-year-old patient had a gastroenterostomy, and one who had associated gall stones had a cholecystectomy. Two others had a partial gastrectomy (Polya and Billroth II) together with cholecystoduodenostomy. In both cases, the ampulla of Vater was impassable due to inflammatory stenosis. When an internal biliary fistula due to an ulcer is found during operation, Marshall and Polk (1958) advocate partial gastrectomy and cholecystectomy, and this was carried out in three of their cases.

Those patients presenting with gall stone ileus will require resuscitation with intravenous electrolytes to correct their water/salt imbalance, and, as the electrolyte depletion may be gross, hypertonic solutions may be required. Surgery is directed to the relief of obstruction by the removal of the stones and a search throughout the small bowel for any other stones which may be present and subsequently produce intestinal obstruction. This is of very real importance if the stone removed is faceted, as it is evidence of an earlier close relationship with other faceted stones within the gall bladder. Usually patients with gall stone ileus are too ill for definitive surgery to remedy the chronic gall bladder disease.

The mortality rate of uncomplicated gall bladder disease treated by cholecystectomy is between 1 and $2 \%$, but this figure is considerably higher in cases of internal biliary fistulae. The patients are commonly elderly with arteriosclerotic disease and will have sustained recurrent attacks of cholangitis with its attendant hepatic damage, and the operation is a prolonged one as the dissection is difficult. These features probably account for the increased operative mortality. Marshall and Polk (1958) record a mortality rate of $12.5 \%$. In this small series of internal biliary fistulae, three patients died following operation. Two of these were cases of gall stone ileus both of which were admitted in gross electrolyte imbalance. The other was a patient aged 76 years who had a cholecystoduodenocolic fistula (Dowse, 1963). This is a mortality rate of $23 \%$.

\section{SUMMARY}

The world literature dealing with spontaneous internal biliary fistulae has been reviewed and a small series of 13 cases presented. It would appear that fistulae due to chronic gall bladder disease are the most common ones found, and especially cholecystoduodenal fistulae. The value of radiology has been outlined. The treatment of fistulae due to gall bladder disease is always surgical whereas fistulae due to penetration of a peptic ulcer may heal on medical treatment; in those cases symptoms arising as a result of complications of the ulcer indicated surgical intervention. The operative 
mortality of cases of internal biliary fistula treated surgically is high. The early surgical treatment of cases of chronic cholelithiasis will reduce the incidence of spontaneous internal biliary fistulae.

I wish to thank the consultant surgeons of the United Cardiff Hospitals for permission to publish records of their cases, and to thank Mr. Leighton Williams of Llandough Hospital for the photographs.

\section{REFERENCES}

Adams, H. D. (1958). Hepaticobiliary involvement of the thorax. Surg. Clin. N. Amer., 38, 611-617.

Aird, I. (1950). Companion in Surgical Studies, p. 804. Livingstone, Edinburgh.

Beaver, M. G. (1929). Cholecystogastrostomy; an experimental study. Arch. Surg., 18, 899-912.

Bisgard, J. D. (1942). In Discussion to paper by Puestow, G. B.

Borman, C. N., and Rigler, L. G. (1937). Spontaneous internal biliary fistula and gallstone obstruction. With particular reference to the roentgenologic diagnosis. Surgery, 1, 349-378.

Carlson, E., and Novacovich, G. (1955). Spontaneous fistulas between the gallbladder and gastrointestinal tract. Surg. Gynec. Obstet., $101,321-330$

Colcock, B. P., and McManus, J. E. (1955). Experiences with 1,356 cases of cholecystitis and cholelithiasis. Ibid., 101, 161-172.
Dean, G. O. (1939). Internal biliary fistula. Surgery, 5, 857-864.

Dowse, J. L. A. (1963). Cholecysto-duodenocolic fistulae due to gall-stones. Brit. J. Surg., 50, 776-778.

Faber, referred to by Frerichs. (1861).

Frerichs, F. T. (1861). A Clinical Treatise on Diseases of the Liver. vol. 2, p. 525. New Sydenham Soc., London.

Hutchings, V. Z, Wheeler, J. R., and Puestow, C. B. (1956). Choledochoduodenal fistula complicating duodenal ulcer: a report of five cases and review of the literature. Arch. Surg., 73, 598-605.

Jordan, P. H., and Stirrett, L. A. (1956. Treatment of spontaneous internal biliary fistula caused by duodenal ulcer. Amer. $J$. Surg., 91, 307-313.

Judd, E. S., and Burden, V. G. (1925). Internal biliary fistula. Ann. Surg., 81, 305-312.

Kehr, referred to by Hutchings et al. (1956).

Marshall, S. F., and Polk, R. C. (1958). Spontaneous internal biliary fistulas. Surg. Clin. N. Amer., 38, 679-691.

Ormandy, L., and Bargen, J. A. (1939). Thrombo-ulcerative colitis associated with cologastric and coloduodenal fistulas. Proc. Mayo. Clin., 14, 550-552.

Puestow, C. B. (1942). Spontaneous internal biliary fistula. Ann. Surg., $115,1043-1054$

Robson, A. W. M. (1909). A lecture on fistula between the stomach and bile passages: with remarks on other internal biliary fistula. Brit. med. J., 1, 1050-1054.

Roth, Schroeder, and Schloth, referred to by Robson.

Wakefield, E. G., Vickers, P. M., and Walters. W. (1939a). Intestinal obstruction caused by gallstones. Surgery, 5, 670-673.

,,$---(1939 b)$. Cholecystoenteric fistulas. Ibid., 5, 674-677. 